\title{
Trend and Issue in Learning Strategy of Tahfiz Model Ulul Albab (TMUA)
}

\author{
Noor Fadilah Ambo, Siti Eshah Mokhsein
}

To Link this Article: http://dx.doi.org/10.6007/IJARBSS/v9-i7/6789

DOI: $10.6007 /$ IJARBSS/v9-i7/6789

Received: 07 May 2019, Revised: 10 June 2019, Accepted: 23 June 2019

Published Online: 30 June 2019

In-Text Citation: (Ambo \& Mokhsein, 2019)

To Cite this Article: Ambo, N. F., \& Mokhsein, S. E. (2019). Trend and Issue in Learning Strategy of Tahfiz Model Ulul Albab (TMUA). International Journal of Academic Research in Business and Social Sciences, 9(7), 14181426.

\section{Copyright: (C) 2019 The Author(s)}

Published by Human Resource Management Academic Research Society (www.hrmars.com)

This article is published under the Creative Commons Attribution (CC BY 4.0) license. Anyone may reproduce, distribute, translate and create derivative works of this article (for both commercial and non-commercial purposes), subject to full attribution to the original publication and authors. The full terms of this license may be seen at: http://creativecommons.org/licences/by/4.0/legalcode

\section{Vol. 9, No. 7, 2019, Pg. 1418 - 1426}




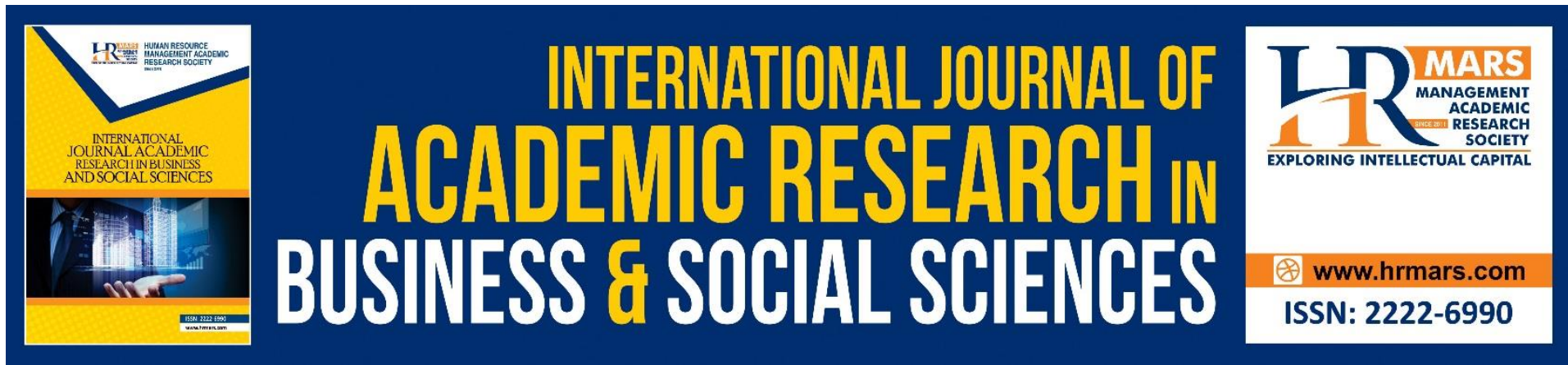

\title{
Trend and Issue in Learning Strategy of Tahfiz Model Ulul Albab (TMUA)
}

\author{
Noor Fadilah Ambo, Siti Eshah Mokhsein \\ Sultan Idris Education University, Perak, Malaysia \\ Email: fadilahambo@gmail.com, eshah@fpm.upsi.edu.my
}

\begin{abstract}
Tahfiz Model Ulul Albab (TMUA) curriculum is a combination of National Curriculum and Kurikulum Bersepadu Tahfiz (KBT) with the Quranic, Encyclopedic and ljtihadik approaches. The conduction of this curriculum is one of the vision of the government in which to produce 125000 hafizs by the year 2050. As a result, tahfiz stream is no longer limited to the students in religious field but instead, is more open and inclusive to all. This trend has resulted in high supports of TMUA curriculum from the community. Nevertheless, research has found that there are four issues should be highlighted in TMUA learning which is not many students memorize the 30 juz of Quran within 3 years, the students do not vary their memorization technique, the learning strategy instruments only focus on the language and the instruments available do not measure the memorization strategy. Hence, this research will explain the significance of learning strategy instruments specifically in memorizing the Quran. Keyword: Tahfiz Model Ulul Albab (TMUA), Memorizing Quran, Learning, Learning Strategy and Instrument Development
\end{abstract}

\section{Introduction}

Islamic education has a long history. Generally, Islamic education grows alongside with the introduction of Islam itself. Began with the arrival of Islam in the Middle East, spread and completed with educational efforts that basically during that time, were not under a formal education system (Azra, 1999). Before the pre-Islamic Arab, education mostly happened at the houses of the companions such as the most wellknown one who is Dar al-Arqam but as the Muslim community established, Islamic education was conducted at mosques.

According to Dahlan (2018), during the early introduction of Islamic Education, it was based to Western education because looking at the source of autonomy and prosperous living at the West that time. Still, the philosophy of Islamic education in the Middle East was still holding to the principles of Tarbiyah, $T a^{\prime}{ }^{\prime}{ }_{i b}$ dan $T a^{\prime} l i m$.

Islamic education progressively entering Asia. Danim (2003) stated that in Indonesia, education acts to develop ability and shape the characters and civilization of a dignified race. This is to develop the students' potentials in order to be human 
beings that are faithful to God, behaved honourably, healthy, knowledgeable, skilful, creative, independent and becoming a democratic and responsible citizens.

Suitable to the purpose of the national education, education is not only making the generations into people that are competent intellectually and emotionally but also competent spiritually. Living within a race and nation, education is the tool to encourage the racial living as stated in the Constitution of the Republic of Indonesia in the year 1945.

Meanwhile in Brunei, the education system has a lot of similarities to the other countries such as the Western countries, Malaysia, Singapore and et cetera. Islamic education system has undergone changes that are initially made personally by the ulama's formally and informally. In coherent to the spread of Islam in Brunei, Islamic Studies (Pendidikan Islam) become one of the subjects implemented at every school. Islamic teaching is the foundation of moral teaching program in Brunei with no negligence to the other subjects. Islamic Education System in Brunei is holistic by upholding akhlak as the bridge of knowledge in achieving improvement in cognitive, affective and psychomotor. (Lubis, Mustapha \& Lampoh, 2009; Nayan, Mahat, Hashim, Saleh, \& Norkhaidi, 2018; Zulfadhli, 2018)

\section{Tahfiz Model Ulul Albab Learning Trend}

The education philosophy in Middle East, Indonesia, Brunei and Malaysia are observed to not be very distinct. Islamic Education Philosophy itself is a process of continuous teaching of knowledge until the knowledge is perceived and absorbed into thoughts, behaviours and action towards self, human beings and surroundings, suitable to the role of humans to be the worshipers of Allah, His leaders and ulama's. Along with that, the development of human capital through education based on al-Quran is able to produce generation of professional and religious experts that are capable to lead the development of the nation dynamically in order to fulfil the government's vision in achieving the National Transformation (TN50) that one of its aspiration is to successfully produces 125,000 hafizs (Mutalib, 2018).

Since 1966, Malaysia's first Prime Minister had a vision of establishing tahfiz centre in Malaysia in order to fulfil the Islamic Education Philosophy in Malaysia. During that time, tahfiz education is conducted formally in Malaysia with the launch of al-Quran and Qiraat Knowledge Learning Class (Pengajian al-Quran dan Ilmu Qiraat) at the National Mosque. This class is under the management of Administrative Committee of Masjid Negara and Malaysia National Council Secretariat of Islamic Affairs from the year 1966 until 1978 (Yusoff, Rahman, Kamri, Ali, Hamzah \& Ramlan, 2018).

If before the tahfiz stream is quite exclusive and accessible to only those in the religious field specifically, however now memorizing al-Quran is more open and inclusive to any interested students and this is also offered at every institution with sufficient facilities provided for the implementation of the tahfiz program, either in pre-schools, primary schools, secondary schools and in tertiary level in the form of certification, diploma and degree (Abbas, 2018).

Along with the government's vision of producing professional huffazs, Tahfiz Model Ulul Albab (TMUA) programme is first introduced in 2005 by the state 
government of Terengganu at Sekolah Menengah Imtiaz, Terengganu (Norhazriah, 2012). Meanwhile at Maktab Rendah Sains Mara (MRSM) is conducted in the year 2009 beginning at MRSM Kota Putra, Besut, Terengganu (Ibrahim \& Manaf, 2016). The success from Sekolah Menengah Imtiaz, Terengganu and MRSM, Malaysia Ministry of Education (MOE) has also conducted TMUA at the MOE's secondary starting 2014 through Kurikulum Bersepadu Tahfiz (KBT) as part of the National Curriculum (Malaysia Ministry of Education, 2016), an-Nur memorization technique and et cetera. TMUA applies the curriculum similar to the mainstream students but with the addition of al-Quran memorization other than the long period of lesson within $6.30 \mathrm{a}$.m. to 4.20 p.m. every day.

TMUA program has received high anticipation from the society proven by the increment of number of schools with Tahfiz Ulul Albab model since 2005 until 2018 (Kementerian Pendidikan Malaysia) in order to accommodate the high applications (Daud, Hussin \& Yama, 2018). Along with the parents' concern of the children's education, tahfiz center in Malaysia are also developing with variety of methods and techniques introduced to facilitate the huffaz's to memorize the Quran such as AlBaghdadi technique, Sulaimaniyah technique at Maahad Tahfiz Sulaimaniyah (Hilmi, 2016) .

Furthermore the ulul albab programme is also implemented in Indonesia at Maahad Al-Zaytun and Maulana State Islamic University (Zainuddin, 2008; Luqman, 2007; Suprayogo, 2004). ulul albab-modelled education began to be recognized in Indonesia education at the end of 90's. Ulul albab approach basically is an ongoing process that forms dynamism in the education field. This education is conducted at Maulana State Islamic University with the objective of producing graduates that are capable in being leaders and able to face the challenges of industrial revolution 4.0 (Abbas, 2018).

There are four categories of schools that conduct Tahfiz Model Ulul Albab (TMUA) in Malaysia which are Sekolah Menengah Kebangsaan Agama (SMKA), Sekolah Berasrama Penuh (SBP), Sekolah Agama Bantuan Kerajaan (SABK) and Maktab Rendah Sains MARA (MRSM).

Referring to the Table 1.1, altogether there are 17116 students from 36 TMUA schools in Malaysia. From the total number, 7438 students are from 11 SMKA schools, 2244 students are from SBP schools, 4348 students are from SABK and 3257 students from 5 MRSM schools.

Table 1.1: The number of Tahfiz Model Ulul Albab (TMUA) schools

\begin{tabular}{|l|l|l|l|}
\hline No. & School & $\begin{array}{l}\text { Number of } \\
\text { school }\end{array}$ & $\begin{array}{l}\text { Total number of } \\
\text { students }\end{array}$ \\
\hline 1. & SMKA & 11 & 7438 \\
\hline 2. & SBP & 4 & 2244 \\
\hline 3. & SABK & 16 & 4348 \\
\hline 4 & MRSM & 5 & 3086 \\
\hline Total & & 36 & 17116 \\
\hline
\end{tabular}

(Source: Ministry of Education (MOE) and MARA Secondary Education Division (BPM) 
Before TMUA is introduced, six al-Quran memorization models are applied at schools and tahfiz institution in Malaysia which are Deobandy al-Quran memorization model from dari India, Panipati model from Pakistan, Luh memorization model from Mekah, Cirebon memorization model from Indonesia, Turkey memorization model and memorization model from Malwali, Bangladesh (Ariffin \& Yusoff, 2017). Each model has differences in the aspect of conducting memorization. Hence, the memorization strategies are also differ according to the compatibility of the models due to the difference in school curriculum.

In addition, effective tahfiz learning strategies also aid in producing professional, technologist and entrepreneurial members that are not only master in academics but also equipped with the knowledge of Quran and as-Sunnah as the generation of Ulul Albab (Nor \& Mokmin, 2015; Ibrahim \& Manaf, 2016). This also supports the institutions and schools that are conducting the Tahfiz Model Ulul Albab (TMUA) programme as an additional curriculum. This model can help facilitate their students especially in the dimension of memorizing process suits to the existing national curriculum. Thus, effective memorization strategies are able to produce excellent students not only excel in academics but also in the aspects of spirituality (Anis \& Sabri, 2017; Azmil, Misnan, Halim \& Aderi, 2014; Hafiz \& Norhanan, 2010; Zubaidah, 2007; Hafiz, Hussin, Azmi, Sulaiman, Kamarul \& Basit, 2005).

In order to achieve the aim of Tahfiz Model Ulul Albab (TMUA) curriculum in which to memorize the 30 juz of Quran, the students should have strategies in their learning as highlighted in the characteristics of Ulul Albab such as quranic, encyclopedic and ijtihadik. Referring to the modul of MRSM Ulul Albab Kota Putra (2009), Ulul Albab is defined as a group that has strong foundation of al-Quran, wide and diverse knowledge, and is capable to think and observe God's creatures through the soul and sharp thoughts and then able to reflect from it. Meanwhile Quranic is referring to those who memorize the 30 juz of Quran and understand the concept of reading (Baca), memorizing (Ingat), comprehending (Faham), thinking (Fikir), practicing (Amal) and spreading (Sebar) (BIFFAS). Students that are encyclopedic are knowledgeable and highly skilled, are referred to also proficient in various fields and languages. ljtihadik is described as students that able to express opinions in solving the problems faced by the ummah, to maximize the brain and mind's capabilities, to think creatively and innovatively and to be highly skill with technology. (Norhazriah, 2012).

Learning strategy is an idea, a behavior, belief or emotion that ease the acquirement, comprehension and transfer of knowledge and new skill (Weinstein, Husman \& Dierking, 2000). To reach the high academic level, the students from various background will have to participate in interaction with numbers of factors such as the school environment, motivation and the student itself (Pintrich \& Groot, 2000). Tuckman (2000) also stated that a student's excellence in academic achievement is a product of interaction between the belief of self-capability through their own selection of learning strategy.

The same goes in the process of memorizing as in memorizing, the process and repetition activity will occur. It is undeniable that memorizing is an activity of keeping knowledge. It actually requires strong mind and is agreed to be a good way in maintaining memories and mind's activity. (Fakhruddin, Ayub, Mutalib \& Jaafar, 
2018). Having a creative strategy and method in memorizing can increase the students' interests, motivations and maintaining focus in their education (Nor \& Mokmin, 2014).

\section{Issues in Tahfiz Model Ulul Albab Education}

Even with the rapid growth of tahfiz schools in Malaysia, yet the curriculum is still traditional with no improvement. Mentioned in Azmil's research (2010) that the objective of TMUA programme is not yet fully achieved as many students are unable to memorize all 30 juz within 3 years. The number of MRSM Kota Putra students that have finished memorize (hafiz) the 30 juz during their fourth year which is in Form 4 is 29 out of 160 students. In the meantime, MRSM Gemencheh produced 19 huffaz's out of 174 and MRSM Kepala Batas managed 38 students out 149 (MARA Secondary Education Division, 2018). These explain that the memorization achievement is not aligned to the academic achievement although there are students who finished (hafiz) during in Form 5 yet, there are still many have failed to achieve the target.

As informed, the students are under the same model which is the Tahfiz Model Ulul Albab (TMUA) however their achievement in memorizing are differ among each other. According to a research conducted by Azmil, Halim, Misnan and Aderi (2014) it is found that some of the factors for the flaws in students' achievement is the students did not vary their memorization techniques and may be due to the lack of exposure from the tahfiz teachers at school.

Besides, the research in educational field has shown that the students with strategy in learning are able to increase their academic achievement (Adnan, Nordin \& Ibrahim, 2018); Marsh, Hau, Artelt, Baumert, \& Peschar (2006); Zimmerman \& Martinez-Pons (1990). It is the same in memorizing the Quran. A good memorizing Quran strategy can facilitate them in improving their memorization achievement. According to Zakiah and Zariruddin (2016) tahfiz learning strategy is determined to be effecting the accomplishment in oral (syafawi) and written (tahriri). These learning strategies are depend on the Quran memorization models.

However, in order to determine the memorization strategy of TMUA students, an effective memorization strategy instrument should be used. However, the researchers found that most learning strategy instruments are used for language education subjects as example the Learning Strategy and Study Inventory (LASSI), Text-Learning Strategy Inventory, Inventory for Language Learning Strategies (CILLS), General Metacognitive Strategies Inventory (GMSI), Strategy Inventory for Language Learning (SILL), Inventory of Ways to Learn Malay Language, Strategy Inventory for Vocabulary Learning.

Only a few instruments are for evaluating the effectiveness of students' learning from the aspect of metacognitive as instance the Learning Strategy Inventory, The School Motivation and Learning Strategy Inventory (SMALSI), Self-Regulated Learning Strategies and Culture Learning Strategies Inventory.

The existing instruments either locally or internationally are not developed to measure the memorization strategy. Moreover, all strategy instruments are traditional, not renewed, not comprehensively measure and also not suitable for the tahfiz students of Ulul Albab Models in Malaysia. 
The researchers also found there is no instrument for measuring the tahfiz learning strategy that is standardized to the Malaysian context which built to measure memorization technique including the cognitive, metacognitive and affective strategies of the students.

\section{Conclusion and Research Recommendation}

The TMUA students' learning strategy should be looked into in order to ensure equal accomplishment of their memorization and academic performance (Nor \& Mokmin, 2016; Azmil, Halim, Misnan \& Aderi, 2014; Rozani, 2013; Misnan \& Yunus, 2003). Acquiring strategy in memorizing is also to create an effective learning process for the students and then contributing something that is with quality for the education of our nation (Ibrahim \& Assaadah, 2011) and to guarantee the qualification of TMUA students to finish their memorization at least before end their studies in MRSM even though not within the 3-years duration as assigned.

Therefore, a recent, valid and highly-reliable Quran Memorization Strategy Instrumen or Instrumen Strategi Menghafaz Quran (ISMEQ) should be developed to evaluate the memorization strategy. Then, in the context of developing the instrument, Rasch measurement model can enhance the achievement of student's performance in memorizations as the Rasch model is able to overcome the flaws in using raw scores as the ability and as items in the framework of the Classical Test Theory (Ariffin, 2013).

According to Mokhsein (2018), Rasch model is the earliest model implementing the Items Response Theory (TRI) because of the main feature of Rasch model is the probability model that is designed to answer the main question which is; when an individual with certain ability (the number of correct items) is given items with parameter of certain difficulty (the number of correct tested items), what is the probability (likelihood) for the individual to answer the items correctly? (Bon \& Fox, 2012). With Rasch model, the probability increases in correspond to the value of item's parameters such as the difficulty parameter and discriminative parameter.

Hence, only Rasch measurement model is determined to be able to solve the problems as it produces linear measurement, is applicable to many data, detects misfits or outliers and produces separated measurement instruments and no longer depending on the parameters of the object observed (Aziz, Masodi \& Zaharim, 2017). Not only that, Rasch model can also detect model's inaccuracy and can produce repeatable measurements.

\section{References}

Azmil, H., Ab, H. T., Misnan, J., \& Aderi, C. N. (2014). Kaedah pembelajaran tahfiz dan hubungannya dengan pencapaian hafazan pelajar. Journal of alQuran and Tarbiyyah.

Azra, A. (1999). Menuju Masyarakat Madani. Bandung: Remaja Rosdakarya.

Azrilah, A. A., Mohd, S. M., \& Azmi, Z. (2017). Asas Model Pengukuran Rasch: Bahagian Pendidikan Menengah MARA.

Bond, T. G. \& Fox, C. M. 2012. Applying the Rasch Model Fundamental Measurement in the Human Sciences. Edisi ke-2. New York: Routledge Taylor \& Francis Group. 
Fathiyah, M. F., Ahmad, F. M. A., Norlizah, C. H., Lukman, A. M., \& Wan, M. W. J. (2018). Pembelajaran Murid Tahfiz Sekolah Agama Kerajaan Di Malaysia: Bentuk Adab dan https://www.bharian.com.my/berita/nasional/2018/01/373115/kerajaan-komitedlahirkan 125000huffaz

Maimun, A. L., Ramlee, M., \& Abdullah, A. L. (2009). Integrated Islamic Education in Brunei Darussalam: Philosophical Issues and Challenges. Journal of Islamic and Arabic Education 1(2), 2009 51-60

Marsh, Hau, Artelt, Baumert, \& Peschar (2006). OECD's Brief Self-Report Measure of Educational Psychology's Most Useful Affective Constructs: Cross-Cultural, Psychometric Comparisons across 25 Countries. International Journal of Testing, v6 n4 p311-360 2006

Meor, I., \& Assaadah. (2011). Kajian Gaya Pembelajaran dalam Kalangan Pelajar UTM. Journal of Educational Psychology and Counseling, volume 2, Jun 2011, Pages 51-77

Mohamad, A. M. A., Mohamad, A. M., Mohd, S. N., Ibrahim, \& Mohd, B. (2013). Relationship between Learning Strategies and Motivation by using Structural Equation Modeling Approach. Malaysian Online Journal of Educational Sciences, v1 n3 p33-40.

Nayan, N., Mahat, H., Hashim, M., Saleh, Y., \& Norkhaidi, S. B. (2018). Verification of the Instrument of Climate Literacy Knowledge among Future Teachers: Confirmatory Factor Analysis (CFA). International Journal of Academic Research in Progressive Education and Development, 7(3), 26-39.

Norhazriah M. O. (2012). Program Ulul Albab Sebagai Suatu Proses Transformasi Pendidikan Malaysia. Kajian Kes: Sek. Men. Imtiaz, Terengganu. Paper Pembentangan dalam Bengkel Antarabangsa PembangunanBerteraskan Islam V(WAPI5), Medan. Retrieve from: http://www.academia.edu/8050819/PROGRAM_ULUL_ALBAB_SUATU_PROS ES

RANFORMASI_PENDIDIKAN_Malaysia_KAJIAN_KES_SEKOLAH_MENENGAH IMTIAZ_TERENGGANU_1

Pembentukan Skala \& Struktur Pengukuran. Bangi: Universiti Kebangsaan Malaysia.

Pintrich, P. R. (2000). Multiple goals, multiple pathways: The role of goal orientation in learning and achievement. Journal of Educational Psychol- ogy, 92(3), 544555.

Rashidi, A., \& Azhar, J. R. (2018). Pendidikan Tahfiz dan Kemahiran Insaniah. Pahang: Universiti Malaysia Pahang.

Siti, E. M. (2018). Aplikasi Teori Respon Item dalam Penyelidikan. Perak:

Siti, R. A., (2003). Teori, konsep \& amalan dalam pengukuran dan penilaian. Bangi: Pusat Pembangunan Akademik UKM.

Siti, S. I., Umi, K. A. M. (2013). Penelitian Terhadap Ciri-ciri Pemilihan Pelajar ke Maktab Rendah Sains MARA Berdasarkan Elemen Sahsiah Bagi Pelaksanaan Kurikulum UlulAlbab. GREDUC

Sudarwan, D., \& Darwis. (2003) Metode Penelitian Kebidanan : Prosedur, Kebijakan, dan Etik. Jakarta: Penerbit Buku Kedokteran EGC. 
Tuckman, B. W. (1979). Evaluating Instructional Programs. London: Allyn\&Bacon, Inc. Universiti Pendidikan Sultan Idris.

Weinstein, C. E., Husman, J., \& Dierking, D. R. (2000). Self-regulation interventions with a focus on learning strategies. In M. Boekaerts, P. R. Pintrich \& M. Zeidner (Eds.), Handbook of self-regulation (pp. 728-744). San Diego, CA: Academic Press.

Zaini, D. (2018). Sejarah Pendidikan Islam. Medan: UIN SU

Zainora, D., Nor, N. H., \& Phayilah, Y. (2018). Proceeding of The International Conference On Contemporary Issues In Al-Quran And Hadith 2018 (THIQAH 2018) $7^{\mathrm{TH}}$ MAC 2018. llim, Bangi, Selangor.

Zanariah A. M. (2018). Kerajaan komited lahirkan 125,000 huffaz. Berita Harian. Retrieved on 10 November 2018, from:

Zimmerman \& Martinez, P. (1990). Student Differences in Self-Regulated Learning: Relating Grade, Sex, and Giftedness to Self-Efficacy and Strategy Use. Journal of Educational Psychology 1990. Vol.82, No.1, 51-59.

Zulfadhli. (2018). Determination of Industrial Competitiveness on Manufacturing Industry Growth in Palembang City, International Journal of Academic Research in Accounting, Finance and Management Sciences 8 (3): 238-254.

Zulkiffli, M. Y., Noor, N. A. R., Nor, A. K., Nor, A. A., Norhayati, H., \& Naeimah, R. (2018). Trend Masyarakat Terhadap Pendidikan Tahfiz. Darul Quran JAKIM. 